NBER WORKING PAPER SERIES

\title{
PAYCHECK RECEIPT AND THE TIMING OF CONSUMPTION
}

\author{
Melvin Stephens Jr. \\ Working Paper 9356 \\ http://www.nber.org/papers/w9356
}

\begin{abstract}
NATIONAL BUREAU OF ECONOMIC RESEARCH 1050 Massachusetts Avenue Cambridge, MA 02138
\end{abstract}

November 2002

\begin{abstract}
I would like to thank Kerwin Charles, Jeff Dominitz, and Lowell Taylor for useful comments. Data from the Family Expenditure Survey is Crown Copyright, made available by the CSO through the ESRC Data Archive, and used by permission. The views expressed herein are those of the authors and not necessarily those of the National Bureau of Economic Research.

(C) 2002 by Melvin Stephens. All rights reserved. Short sections of text, not to exceed two paragraphs, may be quoted without explicit permission provided that full credit, including (C) notice, is given to the source.
\end{abstract}


Paycheck Receipt and the Timing of Conumption

Melvin Stephens Jr.

NBER Working Paper No. 9356

November 2002

JEL No. D91, E21

\section{ABSTRACT}

This paper examines the consumption response to monthly paycheck receipt. Since the amount and arrival date of paychecks are known in advance, the receipt of a paycheck does not coincide with the receipt of new information. Under the basic rational expectations Life-Cycle/Permanent Income Hypothesis, household consumption should not respond to paycheck arrival. Using data from the United Kingdom's Family Expenditure Survey, this paper finds that household consumption is excessively sensitive to paycheck receipt. The results cannot be explained by any underlying monthly expenditure fluctuations common to all households. The presence of liquidity constraints as measured by wealth can account for the excess sensitivity results although the availability of credit cards cannot.

\section{Melvin Stephens Jr.}

H. John Heinz III School of Public Policy and Management Carnegie Mellon University

4800 Forbes Avenue

Pittsburgh, PA 15213

and NBER

mstep@cmu.edu 


\section{Introduction}

References in the literature to the link between the day of paycheck receipt ("pay-day") and worker consumption can be traced back to the beginning of the literature itself. Osborn (1898), writing on the results from a report by the U.S. Commissioner of Labor titled Economic Aspects of the Liquor Problem, presents findings of a nationwide employer survey where roughly 60 percent of employers give an affirmative answer "to the question whether employees were more addicted to the use of intoxicating liquors immediately after payday." In a study of factory wage earners across sixteen cities, the U.S. Department of Labor (1939) found "that in the majority of cases from 75 to 100 percent of the earnings had been spent by the end of the day following pay day." Hilton (1957) reports that for 19th century Scottish miners, the day upon which they could first draw from their monthly earnings "was eagerly anticipated by many of the miners and their wives. Queues of one hundred were common at some of the large [company-run stores where earnings could be spent]."

In recent years, the consumption response to paycheck receipt has been examined as a method for testing the rational expectations version of the Life-Cycle/Permanent Income Hypothesis (LCPIH). According to the model, consumption should not exhibit excess sensitivity to pre-determined fluctuations in the household's paycheck amount if no new information coincides with paycheck arrival. Consistent with the LCPIH, Browning and Collado (2001) find that Spanish households whose payment scheme includes bi-annual "bonus" paychecks do not exhibit differential consumption patterns relative to households whose income is spread evenly throughout the year. Contrary to the LCPIH, Parker (1999) finds contemporaneous consumption increases for U.S. households at the time their take-home pay is increased after having reached the annual maximum Social Security tax contribution. Shapiro and Slemrod (1995) find that households expected to change their monthly spending in response to the 1992 reform in the U.S. income tax-withholding law that simply re-allocated the timing, but not the amount, of after-tax income receipt. As the findings from these studies suggest, whether or not consumption responds to paycheck receipt remains an unresolved issue. 
This paper proposes a new test for examining the consumption response to paycheck receipt. The arrival date as well as the amount of paychecks are known in advance to working households. Since paycheck arrival does not provide any new information to the recipients, the LCPIH predicts that household consumption should not exhibit excess sensitivity to paycheck receipt. The LCPIH is tested in the current study by examining whether the timing of consumption over the calendar month is influenced by the arrival of monthly paychecks. Note the similarity between this test of the LCPIH and the tests discussed in the previous paragraph. Prior studies examined whether consumption responds to known variation in the timing of income receipt across the calendar year (holding permanent income constant). The current paper tests whether consumption responds to known variation in the timing of income receipt across the calendar month. ${ }^{1}$

Increases in expenditures at the time of monthly paycheck receipt are not necessarily a violation of the LCPIH. Households may have mortgage payments, utility bills, etc. that must be paid periodically. Expenditures on items such as toothpaste and breakfast cereals are typically considered non-durable but may be purchased in lumpy amounts over the course of a month. Instead, the expenditures that are relevant for testing the theory are those that will be consumed either instantly or within a relatively short period of time. The primary focus in this paper is on "instant consumption" expenditures in categories such as food and alcohol consumed away from home and fresh foods.

Data from the United Kingdom's Family Expenditure Survey is used to examine the consumption response to paycheck receipt. The survey collects information on household income including the date of paycheck receipt for all household workers. Consumption information is collected by having households record their expenditures over a two-week period. The survey is implemented by evenly spacing households throughout the calendar year and throughout each month. Most importantly, each household's survey participation period is uncorrelated with the date of paycheck arrival. The impact of paycheck receipt on household consumption is identified by comparing households in the survey when their

\footnotetext{
1 In a related paper, Stephens (2002) examines the consumption response of U.S. Social Security recipients to the arrival of their transfer checks.
} 
monthly paycheck arrives with similar households that are not paid during their two-week diary period.

This paper finds a significant increase in consumption at the time of monthly paycheck receipt. Total weekly expenditures increase by 14 percent at the time of paycheck and decline over the duration between paychecks. In the instant consumption categories, expenditures increase significantly at the time of paycheck arrival by roughly 6 percent. Additional analysis that includes weekly paid workers supports the finding that these increases are due paycheck receipt and not to any underlying monthly expenditure fluctuations common to all households. Splitting the sample between liquidity constrained and unconstrained households using a measure of household wealth finds that the presence of these constraints can account for the excess sensitivity findings. However, when the availability of credit cards is used to measure credit market constraints, significant increases in consumption at the time of paycheck arrival are found for both constrained and unconstrained households. Overall, the evidence in this paper shows that households exhibit excess sensitivity to the receipt of their monthly paychecks.

\section{The Data}

The data for this paper are taken from the Family Expenditure Survey (FES) which is a sample of households in the United Kingdom that has been collected on an on-going basis since 1957. Roughly 6,500 households complete the survey annually. The interviews are spaced evenly throughout the year in order to capture seasonal fluctuations in expenditures. When households are initially contacted, they are asked to complete a household questionnaire that gathers general information such as the number of household members, the age of each household member, and an inventory of durable goods possessed by the household. In addition, a separate questionnaire is used to collect income and labor force data for each household member age sixteen and over. Household members are then asked to record all of their expenditures over the ensuing two-week period in an expenditure diary. All expenditures, whether made by cash, check, or credit card, are to be entered into the diary. The monthly Retail Price Index (RPI) is used to convert income and expenditure data into a constant currency (January $1998 £$ ). 
The current study makes use of the fact that the FES asks respondents, if possible, to have available their most recent pay stubs at the time of the initial interview. From each worker, information on the worker's pay frequency (e.g., weekly or monthly) and date of last paycheck is collected in the study. Pay frequency information is not collected for self-employed workers so they are excluded from the analysis. Pay date information is available in the public use version of the FES from 1986 through March 1998. ${ }^{2}$ One important limitation is that information on each worker's most recent pay date is collected prior to the two-week diary period. The arrival date of each worker's next paycheck must be imputed. Thus, whether and/or when the paycheck arrives during (relative to) the diary period is measured with some error. The longer the worker's pay frequency, the higher the probability that some error will occur in determining the next pay date. Details of the procedure to impute the worker's next paydate are discussed in the Data Appendix.

The FES data include a separate record for each expenditure made during the twoweek diary period. Each expenditure record includes information on the type of item that was purchased (e.g., toilet soap, table wines, petrol) and amount of the purchase. Unfortunately, the public use FES expenditure records only report whether the expenditure occurred during the first or second diary week. The unavailability of the exact date of purchase constrains the types of analyses that can be performed along a number of dimensions. First, although it would be preferable to analyze changes in daily expenditures, this paper will examine changes in expenditures between the two diary weeks. Sharp changes in daily expenditures will only be captured by the extent to which they raise weekly expenditures.

Second, and more importantly, estimation of expenditure changes should be attenuated by the imperfect link between the week of expenditure and the arrival of the paycheck. Ideally, the analysis would examine whether expenditures changed beginning with the date of paycheck arrival. Since expenditures are only available weekly, the analysis examines whether expenditures are impacted if a household receives its paycheck at any point during the diary week. Households that only have two days in the diary week to spend their newly

2 Beginning in 1994, the FES has been released to coincide with the tax year which runs from April until March. 
arrived paycheck will be treated identically to households that receive their paychecks on the first day of their diary week.

Third, analyzing the impact of check arrival on the extensive margin, i.e., whether the household makes any expenditures at all, will not produce any meaningful results. For the expenditure categories examined below, over 90 percent (and in some cases nearly 100 percent) of households make purchases during both diary weeks. Thus, the analysis will focus on the effect of paycheck receipt on the amount of weekly expenditure.

The final constraint due to the unavailability of daily expenditure data is that the primary analysis is limited to workers who are paid monthly. With the analysis limited to changes in weekly expenditures, there is no scope to examine the impact of paycheck arrival on consumption for weekly paid workers who are paid during both of their diary weeks. Furthermore, since an examination of the data indicates that nearly all workers in the UK are paid either weekly or monthly, the primary analysis focuses on the latter group of workers. However, since there may be underlying tendencies for all households to make expenditures at specific points during the month (e.g., if stores regularly were to have sales during the second week of the month), the sample of weekly paid workers are examined to determine the impact these types of fluctuations may have on the inferences drawn from the analysis.

The final data consideration is to determine which households to include in the analysis. Aside from labor income, households may receive regular monthly income from one or more additional sources (e.g., government benefits). Furthermore, within a given household there may be multiple paychecks. The analysis in this paper examines the relationship between consumption and the paycheck receipt of the "primary earner." The primary earner is defined as either a head of household or their spouse (if one is present) whose weekly labor income from their main job accounts for at least 50 percent of total weekly household income. ${ }^{3}$ This designation focuses the analysis on the response to receipt of the household's primary income source.

\footnotetext{
3 Defining the primary earner as receiving at least 75 percent of household income yields comparable results to those presented here.
} 
A number of restrictions are placed on the FES data to form the sample used in the analysis. From the original sample of households that participated in the FES between 1986 to March 1998, households without a primary earner are eliminated. These eliminations occur because neither spouse is employed as of the survey date (41 percent of the overall FES households), because the employed spouse(s) are self-employed (5 percent), or because neither spouse earns a large enough share to be deemed the primary earner (16 percent). Of the remaining households with primary earners, the sample is further restricted to households where the primary earner is between the ages of 25 and 59 (inclusive). ${ }^{4}$ In an attempt to increase the precision of the paydate information, the roughly 10 percent of households where a pay stub was not consulted to determine the primary earner's earnings information are deleted. ${ }^{5}$ Finally, some monthly paid households are excluded if one of their diary weeks does not fall within one of the four groupings described in the next section. The final sample of households used in the analysis consists of 12,827 households that have a monthly paid primary earner. In addition, a sample of 7,347 households with weekly paid primary earners, which is formed by applying the above restrictions, is also examined.

\section{Empirical Methodology}

Identification of the impact of paycheck arrival on household consumption is achieved through the sampling scheme used to gather the Family Expenditure Survey data. The FES is collected by randomly selecting the date to interview and begin each household's two-week diary period. In particular, the days of the month during which a household participates in the FES is uncorrelated with the date on which the household receives its paycheck. The impact of paycheck arrival on consumption is identified by comparing diary weeks during which a monthly paid primary earner receives her paycheck against the other

\footnotetext{
4 In the UK, the mandatory retirement age for women is 60 .

5 Other deletions include a small number of households where the difference between their last pay date their interview date exceeded the length of their pay period by a few days, and those households whose diary period did not start within one day of their household interview.
} 
diary weeks for households with monthly paid primary earners. ${ }^{6}$ The solid line in Figure 1 shows the distribution of interview dates across households where the primary earner is paid monthly. As can be seen in the Figure, FES interviews are spread fairly evenly throughout the calendar month although they begin to fall off somewhat towards the end of the calendar month.

Table 1 reports summary statistics for the sample of households with monthly paid primary earners. In Panel A households are divided into four groups depending upon the day of the calendar month on which their two-week diary period began. As the Table indicates, the (mean) observable characteristics are nearly identical across households regardless of when they began the survey during the month. An additional examination of the sample is shown in Panel B of the Table where households are divided into four groups based upon when the next paycheck (of the primary earner) arrives. Again, the observable characteristics are very comparable across the four columns. While these observable similarities cannot rule out unobservable differences across households, the results in the Table are highly suggestive of a random distribution of households entering the survey throughout the calendar month and relative to their paydates.

The equation capturing the consumption response to monthly paycheck receipt is

$$
C_{i t}=\alpha_{i}+\sum_{j=2}^{4} \beta_{j} P A Y W E E K_{j}+\gamma W E E K 2_{i t}+\sum_{k=2}^{31} \delta_{k} D O M_{k}+\epsilon_{i t}
$$

where the dependent variable, $C_{i t}$, is a measure of household $i$ 's consumption during diary week $t$. Equation (1) includes a household specific effect, $\alpha_{i}$, as is common in studies that test the LCPIH. In the current paper, the fixed effect eliminates the need to include indicators for calendar month and year since nearly all of the variation occurs within these time periods. ${ }^{7}$ This equation also controls for "survey fatigue", the possibility that

\footnotetext{
6 As mentioned in the data section, the main analysis is limited to households where the primary earner is paid monthly.

7 Of course, diary periods can fall into two months as well as two years. In the data, a number of interviews do indeed extend into a second calendar month. Specifications that include month dummies yield nearly identical results to those presented here for the coefficients of primary interest. The number of diary periods encompassing two calendar years is negligible.
} 
households may record fewer expenditures as the diary period progresses. The $W E E K 2_{i t}$ variable, which indicates whether the diary week is the household's second week of the survey, accounts for this potentially confounding effect. The $D O M_{k}$ variables are indicators for the day of the calendar month on which the household's diary week began. These variables will capture any fluctuations in expenditures over the calendar month that are not associated with the receipt of the paycheck. Since, as can be seen in Figure 1, the date of paycheck receipt tends to be concentrated near the end of the calendar month, it is important to capture any such fluctuations so that they are not falsely attributed to the paycheck arrival. $\epsilon_{i t}$ is a weekly household specific error term. Notably absent are controls for changes in household composition that are usually present in studies examining the LCPIH. Even though the FES does not include information on changes in household composition between the two diary weeks, the need to include such controls is greatly diminished due to the short duration of the survey.

The coefficients on the $P A Y W E E K_{j}$ indicators are the primary parameters of interest in the analysis. The paycheck arrival information is used to group diary weeks into the following categories: 1) diary weeks during which the primary earner's paycheck is received (i.e., diary weeks which begin zero to six days before the paycheck arrives), 2) diary weeks that begin one to seven days after the paycheck is received, 3) diary weeks that begin eight to fourteen days after the paycheck is received, and 4) diary weeks that begin seven to thirteen days before the paycheck is received. The final category is excluded from the analysis so that the $\beta_{j}$ coefficients on the $P A Y W E E K_{j}$ indicators measure the difference in weekly expenditures relative to the time of the month during which the household will have gone the longest without receiving its primary source of income. ${ }^{8}$

It is worthwhile to note that there is a considerable degree of overlap in terms of the actual days before or since the paydate across these groupings of diary weeks. For example, a diary week that begins on the day of check arrival will be included in the first group while a diary week beginning the day after check arrival will be put into the second group.

\footnotetext{
8 Households with a diary week that does not fit into one of these four categories are excluded from the analysis in order to use the first-difference estimator. Under the assumption that diary start dates are randomly assigned to households, this restriction will not bias the results.
} 
Similarly, a diary week beginning seven days before the check arrives will be assigned to the fourth group while the first group includes households where the diary week begins six days before check arrival. This degree of overlap will attenuate the estimates of any sharp consumption changes due to paycheck arrival and bias the results in favor of the LCPIH.

An important empirical consideration is that households may make no purchases in a category of expenditure at a weekly interval. In prior studies this issue is typically not a concern since at a quarterly or annual frequency virtually all households have a positive expenditure amount. As such, these studies use the log of expenditures as the dependent variable. In the current context, however, the censoring of the dependent variable may preclude the use of log expenditures.

The censoring issue is dealt with in two ways. First, for the expenditure categories considered in this paper, the fraction of zero expenditure diary weeks never exceeds six percent of total diary week observations. Thus, the potential scope for any bias due to ignoring the censoring of the dependent variable is likely minimal. In addition, results will be presented showing the similarity in the point estimates both with and without the zero expenditure diary weeks in the analysis. Hence, the majority of the analysis will follow the previous literature by using a first-difference estimator where the difference in $\log$ expenditures between the two diary weeks is the dependent variable of interest. In this part of the analysis, the estimated equation will be

$$
\Delta\left(\log C_{i t}\right)=\sum_{j=2}^{4} \beta_{j}\left(\Delta P A Y W E E K_{j}\right)+\gamma\left(\Delta W E E K 2_{i t}\right)+\sum_{k=2}^{31} \delta_{k}\left(\Delta D O M_{k}\right)+\Delta \epsilon_{i t},
$$

where, using the standard notation, the difference operator $(\Delta)$ represents the change in the variable between the first and second diary week. ${ }^{9}$

The second, and direct, method for dealing with the censoring of the dependent variable is to use Honoré's (1992) symmetrically trimmed least squares fixed effect censored regression estimator to estimate equation (1). This estimator is consistent even in the presence of the fixed effect in equation (1) whereas including fixed effects in a Tobit estimator

\footnotetext{
9 In equation (2), $\triangle W E E K 2_{i t}$ will equal one for each household so that $\gamma$ is the coefficient on the intercept term for the differenced equation.
} 
would be inconsistent when the number of time periods is small (Heckman and MaCurdy 1980). When the censored regression estimator is used, the estimated marginal effects are reported in lieu of the regression point estimates so that the results can be interpreted directly in terms of the impact on the amount of expenditure. ${ }^{10}$ Bootstrap replications of the model are estimated in order to calculate confidence intervals for the marginal effects. The bootstrapped confidence intervals are calculated by re-estimating the model on 200 replication samples that are created by resampling with replacement from households in the sample.

The analysis focuses on six categories of expenditure. Total expenditures are the sum of all expenditures recorded during the diary week. A second category of expenditure, now routinely used in the literature, is strict non-durables which in the current analysis is comprised of food and alcohol both at home and away from home, tobacco-related items, personal care items, public transportation, gasoline, and motor oil. This expenditure category is typically used in order to limit the analysis to items that likely would be consumed entirely within a calendar quarter (Lusardi 1996). Since food expenditures are also used in many analyses of the LCPIH, food for home consumption is also included as a separate expenditure category.

One difficulty in testing the LCPIH with the above expenditure categories in the current context is that while strict non-durables and food for home consumption are non-durable over quarterly and annual intervals, it is far less likely that these expenditures are necessarily consumed immediately during the diary week. As such, categories of expenditures that are consumed within a diary week are necessary to test the LCPIH over such a short duration. One category that should represent "instant" consumption is food consumed away from home. Fresh foods such as milk, eggs, and fresh fruits and vegetables - items that are perishable over the course of month - are also examined. Finally, a category of total instant consumption is examine that includes food and alcohol away from home, fresh foods, take away food, and entertainment expenses such as cinemas, concerts, and

10 The average population marginal effect corresponding to a regressor $x_{k}$ in a censored regression is calculated as $\beta_{k} * P$ where $\beta_{k}$ is the population coefficient on $x_{k}$ and $P$ is the fraction of non-censored observations in the population (Greene 1981). An estimator for the marginal effect is $\hat{\beta_{k}} * \hat{P}$ where $\hat{\beta_{k}}$ is the estimated regression coefficient and $\hat{P}$ is the fraction of non-censored observations in the sample. 
spectator sport admissions. It is these instant consumption categories that are of primary interest in the analysis.

\section{Results}

Table 2 presents the results of estimating the effect of paycheck arrival on household consumption. Panel A reports the calculated marginal effects from using the censored dependent variable estimator for equation (1). The results in column (1) show a significant increase in total expenditures of $£ 66$ if the paycheck arrives during the diary week. This increase is roughly 16 percent of the average total weekly spending of $£ 408$. In addition, total expenditure remains higher during the week following check arrival since the results indicate a significant increase in total spending if the diary week begins one to seven days after the receipt of the paycheck. The positive but insignificant result for a diary week beginning eight to fourteen days after check arrival is consistent with a pattern of increased spending at the time of the month when the paycheck is received and a falling off the longer it has been since the check arrival date.

The monthly patterns for strict non-durables (column 2) and food at home (column 3) are similar to the results for total expenditure in that spending in these categories increases when the paycheck arrives and then falls off over the ensuing weeks. Strict non-durables increase by $£ 8.5$, or 7 percent of average weekly spending, during the week when the paycheck arrives. Spending in this category is also significantly higher during the week after check arrival before decreasing later in the month. Food at home expenditure is not only significantly higher during the week when the paycheck arrives, but also remains higher for the following two weeks.

The categories of instantaneous consumption expenditures that are most relevant for

testing the Life-Cycle/Permanent Income Hypothesis are shown in the final three columns of the Table. Food away from home consumption significantly increases by 5 percent during the week of paycheck arrival. Consumption of fresh foods significantly increases by 4 percent during the week of paycheck arrival. Overall, total instant consumption (column 6) significantly increases by roughly 5 percent when households receive their monthly paychecks. As with the other expenditure categories, spending in these instant consumption 
categories declines during the weeks following paycheck arrival. Although these effects are not large in magnitude, they nevertheless indicate a consumption response to the arrival of monthly paychecks.

While the results in panel A examine how the amount of weekly expenditures respond to the arrival of a monthly paycheck, most prior tests of the LCPIH examine the change in the log rather than the level of expenditures. In the current analysis, log consumption cannot be used for households with diary weeks during which no expenditures are recorded. As can be seen in panel A, however, weekly expenditures are non-zero for nearly all diaryweek observations across all of the categories examined. When the sample is limited to households with non-zero expenditures for both diary weeks, the fraction of households remaining ranges from 91.5 percent (for food away from home) to 99.6 percent (for total expenditures). Thus, examining the change in log expenditures as is typically done likely will not impart much of a bias on the estimated parameters. To gauge the extent of the bias from using only the non-zero expenditure diary weeks, Appendix Table 1 uses a firstdifference OLS estimator to examine the change in the level of weekly expenditures for households with non-zero expenditures during both diary weeks. ${ }^{11}$ The estimated results are very similar to the estimated marginal effects in panel A of Table 2 even for the categories of expenditures with the most zero expenditure weeks (food away from home and fresh foods). These estimates suggest that restricting the sample to the non-zero expenditure weeks results in a negligible bias since only a small fraction of the sample is eliminated. Thus, the remainder of the analysis will examine the change in the log of expenditures as is common throughout the literature. ${ }^{12}$

Panel B of Table 2 shows the outcome of estimating the impact of monthly paycheck arrival on the log of weekly expenditures. The results from this analysis lead to nearly

\footnotetext{
11 With only two observations per household and non-zero diary-week observations, applying OLS to the first-difference in the level of expenditure is identical to using Honoré's estimator on the exact same sample.

12 An added benefit of using logs in the current paper is that allows for a straightforward comparison between weekly paid and monthly paid households as will be done below. Comparing the changes in levels between these two sets of households is difficult because of the higher expenditure levels for monthly paid households. The log specification allows for the more parsimonious comparison of percentage changes between households with different pay frequencies.
} 
identical inferences about the effect of check arrival on consumption as were drawn from panel A. For all of the parameter estimates that are statistically significant in panel A, the analogous parameter estimates in panel B are also significant. Furthermore, the implied magnitudes of the effects on weekly spending are the same in both panels of the Table. The only change of note between panels A and B occurs in the food away from home category. While the effect for the week of check arrival is significant in Panel A, the effects for the week during and immediately following check arrival are highly significant in Panel B. These results still show the same monthly pattern - an increase in spending during the week the check arrives that falls off over the course of the month. It is important to note that the change between panels $\mathrm{A}$ and $\mathrm{B}$ for food away from home is not due to the change in the sample between the panels. Both Panel A of Table 2 and Appendix Table 1 yield almost identical parameter estimates when using either the full sample or the sample of households with non-zero expenditures during both weeks. As such, the difference between panels $\mathrm{A}$ and $\mathrm{B}$ is due to the change in the functional form of the dependent variable.

One possible objection to the results in Table 2 is that households may choose their pay frequency. The exact mechanism of selection into the monthly paid households is a priori ambiguous. On the one hand, households that are relatively patient may choose to be paid only once a month since they do not need immediate access to their earnings. On the other hand, households that have self-control problems with their spending decisions may choose to be paid monthly to impose a constraint on their own consumption behavior. No matter the source of selection, assuming it exists, the consumption response is identified within the set of monthly paid households. Thus, the results can be interpreted as showing that monthly paid households exhibit excess sensitivity to paycheck receipt.

Another objection to the results in Table 2 may be that the arrival of monthly paychecks is closely linked to monthly fluctuations in expenditures that are common across all households. Specifically, the arrival of monthly paychecks may all occur at the point in the month when households tend to make a majority of their purchases. If so, then the findings in Table 2 are not evidence against the LCPIH but rather the result of spurious correlation.

However, the case for a spurious correlation explanation of the results is weak. First, following equation (1), all of the regressions in Table 2 include indicator variables for the 
day of the month on which the diary week began. Thus, the results in Table 2 represent the effects of paycheck arrival above and beyond any common monthly fluctuations in expenditures. Second, there is a degree of variation in the timing of monthly paycheck arrival. The dashed line in Figure 1 shows the arrival day of month for the last paycheck received by the sample of monthly paid households. Although a majority of the arrival dates are concentrated in the latter part of the month, there is a considerable degree of heterogeneity in these dates across households.

Finally, if this type of spurious correlation is biasing the results, then the presence of monthly fluctuations in expenditures also should exist for households where the primary earner is not paid monthly. In particular, one can test whether such a pattern exists for weekly paid primary earners. The advantage of examining weekly paid households is that these workers are paid during both of their diary weeks. Since monthly periodicity in expenditures for these households cannot be attributed to paycheck arrival, any changes in expenditures over the course of the month must be due to other factors that potentially affect both weekly and monthly paid households. Although, as can be seen in panel B of Table 1, weekly paid workers are paid less than their monthly paid counterparts, percentage changes (i.e., changes in the log of expenditure) can be compared across these two types of households.

To examine the monthly fluctuations in expenditures for weekly paid workers, the regression model is specified as

$$
\Delta\left(\log C_{i t}\right)=\sum_{k=2}^{4} \theta_{k}\left(\Delta W K O M_{k}\right)+\phi\left(\Delta W E E K 2_{i t}\right)+\nu_{i t} .
$$

In this specification, the $W K O M_{k}$ variables collect diary weeks into four groups: diary weeks beginning on the 1st to the 7th day of the calendar month (the excluded group), diary weeks beginning on the 8 th to the 14 th, diary weeks beginning the 15 th to the 21 st, and those beginning on the 22nd to the 31st. If expenditures differ across the calendar month, this specification should capture these fluctuations. ${ }^{13}$

\footnotetext{
13 Ideally, one could examine the pattern of each of the estimated coefficients on the $D O M_{k}$ indicator variables from equation (1). However, these parameters cannot be precisely estimated in the sample.
} 
The results of estimating equation (3) on the sample of weekly paid workers are reported in panel A of Table 3. If periodic payments such as rent and utility bills are due at the beginning of the month then one would expect that diary weeks overlapping the beginning of the month - those which begin at the end of the month - would exhibit an increase in spending. Total expenditure is 2 percent higher for diary weeks beginning the last week of the month relative to those beginning during the first week of the month, although this increase is insignificant. The results across the remaining expenditure categories suggest that if any pattern is present at all, there is a fall in expenditures over the course of the calendar month. Overall, the examination of weekly paid households shows no evidence of systematic expenditure fluctuations over the course of the calendar month. Of course, such effects may exist but the estimates may attenuate any specific day of the month spending changes because the precise day of spending cannot be examined in the FES data. On the other hand, such attenuation effects also would be present for the estimates of paycheck arrival for monthly paid households in Table 2 .

Equation (3) also can be estimated for the sample of monthly paid households. Unlike for the weekly paid households, any estimated spending fluctuations over the course of the month for monthly paid households may be due either to paycheck receipt or to those factors common to all households. The results of these estimates are presented in panel B of Table 3. Across all of the expenditure categories, there is an increase in expenditures for diary weeks beginning the last week of the calendar month relative to diary weeks that start the first week of the month. With the exception of food away from home spending, these estimates are statistically significant. ${ }^{14}$ As Figure 1 has shown, the majority of paychecks are received during the last week of the calendar month. Thus, a portion of the fluctuations found for monthly paid workers is due to the receipt of paychecks. Overall, the results in Table 3 provide additional evidence that the receipt of paychecks influences the timing of consumption for monthly paid workers. ${ }^{15}$

\footnotetext{
14 Food away from home expenditures are significant at the 13 percent level.

15 Estimation of equation (3) that combines both weekly and monthly paid households but allows the effects to differ between the household's pay frequency yields similar results to those found in Table 3 .
} 
One possible reason why households exhibit a consumption response to the receipt of their monthly paycheck is the presence of liquidity constraints (Zeldes 1989; Runkle 1991). Households that are unable to access capital markets cannot borrow to "smooth" consumption in response to predictable changes in income. Previous research has found evidence that borrowing constraints influence consumption decisions in response to changes in annual or quarterly income (e.g., Jappelli, Pischke, and Souleles 1998).

Studies that test for the effect of liquidity constraints proceed by first splitting the sample into constrained and unconstrained households and then performing the analysis separately on both sets of households. To divide the sample between constrained and unconstrained households, most studies use household wealth, preferably a measure of liquid wealth that can be used to smooth over income fluctuations. Although the FES does not contain information on each household's stock of wealth, information on the income derived from assets is collected. Households are considered to be borrowing constrained if they do not report any asset income (17 percent of monthly paid households). Households are considered to be unconstrained if they are in the top 25 percent of the asset income distribution for monthly paid households. The latter group is limited to the top end of the distribution in order to minimize the likelihood that constrained households are included inadvertently in the group of unconstrained households.

The results of estimating (2) separately for the no asset and high asset households are reported in Table 4. The estimates show quite different outcomes for the two sets of households. For the no asset households in Panel A of the Table, sharp increases in total, strict non-durable, and food for home expenditures are found at the time of paycheck arrival. As with the findings for all households in Table 2, these increases fall off over the remainder of the time between pay dates. Significant increases are also found in the instant consumption categories. Food away from home exhibits a marginally significant increase during the week of check arrival (at the 11 percent level of significance) and during the week following check arrival. Fresh food expenditures increase significantly upon check arrival while the overall impact on instant consumption (column 6) is significant.

High asset households exhibit little evidence of excess sensitivity. Total spending significantly increases upon check arrival for these households. However, these increases likely 
reflect periodic payments such as mortagages and should not be taken as evidence against the LCPIH. For the three instant consumption categories, there is some evidence against the LCPIH although it is very weak. The magnitude of the increase for food away from home is comparable with the results for all households shown in Table 2 but the estimates are insignificant. Only the overall instant consumption category is significant, but even then only at the 10 percent level. Thus, the excess sensitivity to paycheck receipt is consistent with the presence of liquidity constraints as usually measured in the literature.

While the above results use methods consistent with the previous literature to divide the sample between constrained and unconstrained households, there exists a potentially better indicator for the presence of liquidity constraints. For each adult household member in the FES, the FES asks whether or not that individual possesses a credit card. Since credit cards are useful mechanisms for short-term smoothing between paydates, households are considered to be borrowing constrained if no household member possesses a credit card. Using to this delineation of constrained and unconstrained households, 20 percent of monthly paid households are liquidity constrained. In comparison to the asset income method for defining constrained households, only one-third of households that have no asset income do not have a credit card. In addition, 70 percent of households without a credit card possess some asset income. Thus, the set of households defined as liquidity constrained by their lack of credit cards differ substantially from those who are deemed to be constrained due to their lack of asset income.

Table 5 presents the results of first splitting the sample into households with and without credit cards and then separately estimating equation (2) for both groups. The results show different effects for households without access to credit cards and those possessing credit cards. For households without credit cards (Panel A), paycheck receipt increases total expenditures by 20 percent, strict non-durable expenditures by 12 percent, and food for home expenditures by 17 percent. These households also show large and significant increases for the instantaneous consumption categories. Food away from home increases 10 percent upon receipt of the paycheck while fresh food expenditures increase 14 percent. Total instant consumption rises by 11 percent upon receipt of the paycheck. In the weeks following paycheck receipt, expenditures begin to fall off for households without credit 
cards across all categories except food away from home. In the latter category, the fact that all of the regression coefficients are statistically significant relative to the week prior to paycheck arrival suggests that these households tend to dine out until they run out of "discretionary" money and have to wait until their next paycheck before they will again eat out. Overall, the impact of check arrival on consumption is slightly larger in magnitude when constrained households are defined by credit cards rather than by asset income.

For households with credit cards (Panel B), the estimated coefficients are smaller in magnitude than the corresponding results for the constrained households. Somewhat surprisingly, however, these unconstrained households also exhibit sensitivity to the receipt of their monthly paychecks. Most relevant for the LCPIH, these households show a small, yet statistically significant response for the instant consumption categories. Thus, the presence of credit cards does not entirely offset the spending response to paycheck receipt. ${ }^{16}$ One possible reason for these results is that while not having a credit card may signal the presence of credit market constraints, having a credit card may not necessarily mean the household is unconstrained. Thus, although credit cards can help households smooth very short term fluctuations between paychecks, possessing these cards cannot cannot fully explain the excess sensitivity results found in this paper.

\section{Summary}

This paper examines the consumption response to monthly paycheck receipt. Since the amount and arrival date of paychecks are known in advance, the receipt of a paycheck does not correspond to the receipt of new information. Under the basic Life-Cycle/Permanent Income Hypothesis, household consumption should not be sensitive to paycheck arrival. Using data from the United Kingdom's Family Expenditure Survey, this paper finds that household consumption is excessively sensitive to paycheck receipt. Most relevant to testing the LCPIH, expenditures in categories of instant consumption exhibit this sensitivity as

\footnotetext{
16 In results not shown here, households both with and without credit cards are included in the same regression model and the effect of check arrival is allowed to differentially affect the two sets of households in order to formally test whether the response differed significantly. The results cannot reject the null hypothesis that the effects are the same for both groups for all of the expenditure categories. However, the finding that households without credit cards respond to the arrival of their paychecks remains, of course, unchanged.
} 
well. The results cannot be explained by any underlying monthly expenditure fluctuations since no such patterns are found for households that are paid weekly. When the presence of liquidity constraints are defined by the household's wealth as measured by investment income, these capital market imperfections explain the excess sensitivity results. However, the availability of credit cards to smooth consumption between paychecks cannot explain the findings. Although the magnitude of the estimated effects do not suggest large deviations from perfect consumption smoothing behavior, the overall results reject the basic hypothesis. 


\section{Data Appendix}

This data appendix describes the procedure used to determine the relationship between each diary week and the arrival date of a monthly paid primary earner's paycheck. The public use version of the Family Expenditure Survey includes information on the date of the initial interview, the date the diary period began (which is typically the same as the interview date), and, for each household member who has been employed (excluding the self-employed), the arrival date of that member's the last paycheck. Since the paydate information is collected prior to the two-week diary period, it is first necessary to impute the date of the next paycheck in order to determine if the household will be paid during the diary period.

For households that are paid monthly, the date of the next paycheck is assigned by assuming the paycheck will be received on the same day of the following month as it arrived in the current month. For example, if the last paycheck arrives on August 15th, 1996, the next paycheck is assumed to arrive on September 15th, 1996. This approach will measure the date of the next paycheck with some noise. If the last paycheck was not

received on its usual date due to a holiday or weekend, then the next paycheck will be incorrectly assigned. Similarly, if the next paycheck falls on a weekend or holiday, it also will be incorrectly assigned.

Diary weeks are then assigned to one of the four $P A Y W E E K_{j}$ included in equation (1). The assignment procedure differs depending upon whether it is the household's first diary week or its second week. The assignments are described in Appendix Table 3. 


\section{Bibliography}

Browning, Martin and M. Dolores Collado (2001) "The Response of Expenditures to Anticipated Changes: Panel Data Estimates," American Economic Review, 91, 3, 681-92.

Greene, William H. (1981) "On the Asymptotic Bias of the Ordinary Least Squares Estimator of the Tobit Model," Econometrica, 49, 2, 505-13.

Heckman, James J. and Thomas E. MaCurdy (1980) "A Life Cycle Model of Female Labour Supply," Review of Economic Studies, 47, 1, 47-74.

Hilton, George W. (1957) "The British Truck System in the Nineteenth Century," Journal of Political Economy, 65, 3, 237-56.

Honoré, Bo E. (1992) "Trimmed LAD and Least Squares Estimation of Truncated and Censored Regression Models with Fixed Effects," Econometrica, 60, 3, 533-565.

Jappelli, Tullio, Jorn-Steffen Pischke, and Nicholas S. Souleles (1998) "Testing for Liquidity Constraints in Euler Equations With Complementary Data Sources," Review of Economics and Statistics, 80, 1, 251-62.

Lusardi, Annamaria (1996) "Permanent Income, Current Income, and Consumption: Evidence from Two Panel Data Sets," Journal of Business and Economic Statistics, 14, $1,81-90$.

Osborn, Christabel (1898) "Economic Aspects of the Liquor Problem," The Economic Journal, 8, 32, 572-77.

Parker, Jonathan A. (1999) "The Reaction of Household Consumption to Predictable Changes in Social Security Taxes," American Economic Review, 89, 4, 959-73.

Runkle, David E. (1991) "Liquidity Constraints and the Permanent-Income Hypothesis," Journal of Monetary Economics, 27, 1, 73-98.

Shapiro, Matthew D. and Joel Slemrod (1995) "Consumer Response to the Timing of Income: Evidence from a Change in Tax Withholding," American Economic Review, 85, 1, 274-83. 
Stephens Jr., Melvin (2002) “'3rd of tha Month': Do Social Security Recipients Smooth Consumption Between Checks?," National Bureau of Economic Research Working Paper \#9135.

United States Department of Labor (1939) "Spending Habits of Factory Workers," Monthly Labor Review, 48, 1, 104-5.

Zeldes, Stephen P. (1989) "Consumption and Liquidity Constraints: An Empirical Investigation," Journal of Political Economy, 97, 2, 305-46. 
Table 1: Summary Statistics ${ }^{a}$

Households Where the Primary Earner is Paid Monthly

\begin{tabular}{|c|c|c|c|c|}
\hline \multicolumn{5}{|c|}{ Panel A. Grouped Relative to the Day of the Calendar Month } \\
\hline & \multicolumn{4}{|c|}{ First Day of Diary Period Is } \\
\hline & $\begin{array}{l}1 \text { st to } 7 \mathrm{th} \\
\text { of Month }\end{array}$ & $\begin{array}{l}\text { 8th to } 14 \text { th } \\
\text { of Month }\end{array}$ & $\begin{array}{l}15 \text { th to } 21 \mathrm{st} \\
\text { of Month }\end{array}$ & $\begin{array}{c}22 \text { nd to } 31 \text { st } \\
\text { of Month }\end{array}$ \\
\hline \multicolumn{5}{|l|}{ Primary Earner's: } \\
\hline Age & $\begin{array}{c}40.1 \\
(0.17)\end{array}$ & $\begin{array}{c}40.1 \\
(0.16)\end{array}$ & $\begin{array}{c}39.6 \\
(0.16)\end{array}$ & $\begin{array}{c}39.6 \\
(0.15)\end{array}$ \\
\hline Gender $($ Male $=1)$ & $\begin{array}{c}0.75 \\
(0.01)\end{array}$ & $\begin{array}{c}0.75 \\
(0.01)\end{array}$ & $\begin{array}{c}0.74 \\
(0.01)\end{array}$ & $\begin{array}{c}0.72 \\
(0.01)\end{array}$ \\
\hline Years of Education & $\begin{array}{c}11.9 \\
(0.06)\end{array}$ & $\begin{array}{l}11.9 \\
(0.05)\end{array}$ & $\begin{array}{l}11.9 \\
(0.05)\end{array}$ & $\begin{array}{l}12.0 \\
(0.05)\end{array}$ \\
\hline Weekly Income & $\begin{array}{l}458 \\
(5)\end{array}$ & $\begin{array}{l}462 \\
(4)\end{array}$ & $\begin{array}{l}459 \\
(4)\end{array}$ & $\begin{array}{l}471 \\
(4)\end{array}$ \\
\hline Weekly Household Income & $\begin{array}{l}613 \\
(6)\end{array}$ & $\begin{array}{l}620 \\
(5)\end{array}$ & $\begin{array}{l}625 \\
(6)\end{array}$ & $\begin{array}{l}643 \\
(6)\end{array}$ \\
\hline Number of Households & 2,681 & 3,281 & 3,372 & 3,493 \\
\hline \multicolumn{5}{|c|}{ Panel B. Grouped Relative to the Paycheck Arrival Date } \\
\hline & \multicolumn{4}{|c|}{ First Day of Diary Period Is } \\
\hline & $\begin{array}{c}7 \text { to } 13 \text { Days } \\
\text { Before Paydate }\end{array}$ & $\begin{array}{c}0 \text { to } 6 \text { Days } \\
\text { Before Paydate }\end{array}$ & $\begin{array}{c}1 \text { to } 7 \text { Days } \\
\text { After Paydate }\end{array}$ & $\begin{array}{l}8 \text { to } 14 \text { Days } \\
\text { After Paydate }\end{array}$ \\
\hline $\begin{array}{l}\text { Primary Earner's: } \\
\text { Age }\end{array}$ & $\begin{array}{l}40.0 \\
(0.15)\end{array}$ & $\begin{array}{c}39.6 \\
(0.16)\end{array}$ & $\begin{array}{c}39.9 \\
(0.16)\end{array}$ & $\begin{array}{c}39.8 \\
(0.18)\end{array}$ \\
\hline Gender $($ Male $=1)$ & $\begin{array}{c}0.73 \\
(0.01)\end{array}$ & $\begin{array}{c}0.74 \\
(0.01)\end{array}$ & $\begin{array}{c}0.75 \\
(0.01)\end{array}$ & $\begin{array}{c}0.74 \\
(0.01)\end{array}$ \\
\hline Years of Education & $\begin{array}{l}11.9 \\
(0.05)\end{array}$ & $\begin{array}{l}11.9 \\
(0.05)\end{array}$ & $\begin{array}{l}11.9 \\
(0.05)\end{array}$ & $\begin{array}{l}12.0 \\
(0.06)\end{array}$ \\
\hline Weekly Income & $\begin{array}{l}461 \\
(4)\end{array}$ & $\begin{array}{l}461 \\
(4)\end{array}$ & $\begin{array}{l}470 \\
(4)\end{array}$ & $\begin{array}{l}460 \\
(5)\end{array}$ \\
\hline Weekly Household Income & $\begin{array}{l}622 \\
(5)\end{array}$ & $\begin{array}{l}629 \\
(6)\end{array}$ & $\begin{array}{l}637 \\
(6)\end{array}$ & $\begin{array}{c}614 \\
(6)\end{array}$ \\
\hline Number of Households & 3,776 & 3,059 & 3,394 & 2,598 \\
\hline
\end{tabular}

${ }^{a}$ Standard errors are reported in parentheses. 


\section{Table 2: Impact of Paycheck Arrival on Weekly Expenditures ${ }^{a}$ Households Where the Primary Earner is Paid Monthly}

\begin{tabular}{|c|c|c|c|c|c|c|}
\hline \multicolumn{7}{|c|}{ Panel A. Effect on the Amount of Weekly Expenditure ${ }^{b}$} \\
\hline Ind. Variable & $\begin{array}{c}\text { Total } \\
\text { Spending } \\
(1) \\
\end{array}$ & $\begin{array}{c}\text { Strict } \\
\text { Non-dur. } \\
(2) \\
\end{array}$ & $\begin{array}{c}\text { Food } \\
\text { for Home } \\
(3) \\
\end{array}$ & $\begin{array}{c}\text { Food } \\
\text { Away } \\
(4) \\
\end{array}$ & $\begin{array}{c}\text { Fresh } \\
\text { Food } \\
(5) \\
\end{array}$ & $\begin{array}{l}\text { Instant } \\
\text { Cons. } \\
(6)\end{array}$ \\
\hline \multicolumn{7}{|l|}{ Diary week: } \\
\hline overlaps paycheck & $66.4^{* * *}$ & $8.47^{* * *}$ & $5.60^{* * *}$ & $1.44^{* *}$ & $0.36^{* *}$ & $1.97^{* * *}$ \\
\hline receipt & {$[42.3,107.9]$} & {$[5.76,10.70]$} & {$[4.13,6.97]$} & {$[0.07,3.16]$} & {$[0.11,0.67]$} & {$[0.54,3.51]$} \\
\hline begins week after & $88.2^{* * *}$ & $5.81^{* * *}$ & $3.73^{* * *}$ & 1.56 & 0.29 & 1.30 \\
\hline paycheck receipt & {$[33.6,153.8]$} & {$[2.67,8.85]$} & {$[1.67,5.73]$} & {$[-0.34,3.57]$} & {$[-0.05,0.65]$} & {$[-0.70,3.15]$} \\
\hline begins two weeks after & 22.5 & 1.30 & $2.25^{* *}$ & 0.0005 & 0.02 & -0.31 \\
\hline paycheck receipt & {$[-10.9,52.0]$} & {$[-1.72,3.99]$} & {$[0.12,4.22]$} & {$[-1.34,1.48]$} & {$[-0.33,0.39]$} & {$[-1.66,0.99]$} \\
\hline Mean Weekly Expenditures & $£ 408$ & $£ 124$ & $£ 55$ & $£ 30$ & $£ 9.1$ & $£ 46$ \\
\hline$\%$ Non-Zero Observations & 0.998 & 0.997 & 0.988 & 0.947 & 0.957 & 0.994 \\
\hline Number of Households & 12,827 & 12,827 & 12,827 & 12,827 & 12,827 & 12,827 \\
\hline \multicolumn{7}{|c|}{ Panel B. Effect on Log Weekly Expenditure ${ }^{c}$} \\
\hline \multirow{2}{*}{$\begin{array}{l}\text { Diary week: } \\
\text { overlaps paycheck } \\
\text { receipt }\end{array}$} & & & & & & \\
\hline & $\begin{array}{c}0.145^{* * *} \\
(0.015)\end{array}$ & $\begin{array}{l}0.069^{* * *} \\
(0.010)\end{array}$ & $\begin{array}{c}0.088^{* * *} \\
(0.015)\end{array}$ & $\begin{array}{c}0.057^{* * *} \\
(0.019)\end{array}$ & $\begin{array}{c}0.057^{* * *} \\
(0.016)\end{array}$ & $\begin{array}{c}0.061^{* * *} \\
(0.013)\end{array}$ \\
\hline $\begin{array}{l}\text { begins week after } \\
\text { paycheck receipt }\end{array}$ & $\begin{array}{c}0.125^{* * *} \\
(0.019)\end{array}$ & $\begin{array}{c}0.040^{* * *} \\
(0.013)\end{array}$ & $\begin{array}{c}0.066^{* * *} \\
(0.019)\end{array}$ & $\begin{array}{c}0.075^{* * *} \\
(0.024)\end{array}$ & $\begin{array}{c}0.026 \\
(0.020)\end{array}$ & $\begin{array}{c}0.049^{* * *} \\
(0.017)\end{array}$ \\
\hline $\begin{array}{l}\text { begins two weeks after } \\
\text { paycheck receipt }\end{array}$ & $\begin{array}{l}0.038^{* *} \\
(0.017)\end{array}$ & $\begin{array}{c}0.010 \\
(0.011)\end{array}$ & $\begin{array}{l}0.044^{* *} \\
(0.017)\end{array}$ & $\begin{array}{l}0.038^{*} \\
(0.023)\end{array}$ & $\begin{array}{c}0.011 \\
(0.018)\end{array}$ & $\begin{array}{c}0.018 \\
(0.016)\end{array}$ \\
\hline Number of Households & 12,780 & 12,744 & 12,545 & 11,736 & 11,860 & 12,698 \\
\hline
\end{tabular}

${ }^{a}$ All regressions include indicator variables for day of the month on which the diary week began and an indicator for whether the diary week is the second week of the two-week diary period. ${ }^{*},{ }^{* *}$, and ${ }^{* * *}$ represent significance at the $10 \%, 5 \%$, and $1 \%$ levels, respectively.

${ }^{b}$ Panel A reports the marginal effects calculated after estimating Honoré's symmetrically trimmed least squares estimator for censored regressions with fixed effects using the weekly amount of expenditure in the category as the dependent variable. The $95 \%$ confidence intervals for the estimates are calculated from 200 bootstrap replications and reported in brackets. Calculation of the marginal effects and their associated confidence intervals is detailed in the text.

${ }^{c}$ Panel B reports the regression coefficients from using a first difference estimator where the dependent variable is the change in the log of expenditure in the category as the dependent variable. The reported standard errors are adjusted for heteroskedasticity. 


\begin{tabular}{|c|c|c|c|c|c|c|}
\hline \multicolumn{7}{|c|}{ Table 3: Impact of Paycheck Arrival on Log Weekly Expenditure ${ }^{a}$} \\
\hline \multicolumn{7}{|c|}{ Panel A. Households Where the Primary Earner is Paid Weekly } \\
\hline Ind. Variable & $\begin{array}{c}\text { Total } \\
\text { Spending } \\
(1) \\
\end{array}$ & $\begin{array}{c}\text { Strict } \\
\text { Non-dur. } \\
(2) \\
\end{array}$ & $\begin{array}{c}\text { Food } \\
\text { for Home } \\
(3) \\
\end{array}$ & $\begin{array}{c}\text { Food } \\
\text { Away } \\
(4) \\
\end{array}$ & $\begin{array}{c}\text { Fresh } \\
\text { Food } \\
(5) \\
\end{array}$ & $\begin{array}{c}\text { Instant } \\
\text { Cons. } \\
(6) \\
\end{array}$ \\
\hline $\begin{array}{l}\text { Diary week begins: } \\
\text { on } 8 \text { th through } 14 \text { th } \\
\text { of the month }\end{array}$ & $\begin{array}{c}0.009 \\
(0.015)\end{array}$ & $\begin{array}{c}0.00005 \\
(0.009)\end{array}$ & $\begin{array}{c}0.004 \\
(0.014)\end{array}$ & $\begin{array}{c}0.013 \\
(0.022)\end{array}$ & $\begin{array}{l}-0.011 \\
(0.017)\end{array}$ & $\begin{array}{c}0.013 \\
(0.015)\end{array}$ \\
\hline $\begin{array}{l}\text { on } 15 \text { th through } 22 \mathrm{nd} \\
\text { of the month }\end{array}$ & $\begin{array}{c}0.015 \\
(0.018)\end{array}$ & $\begin{array}{c}0.002 \\
(0.011)\end{array}$ & $\begin{array}{c}0.028 \\
(0.017)\end{array}$ & $\begin{array}{l}-0.010 \\
(0.025)\end{array}$ & $\begin{array}{l}-0.001 \\
(0.021)\end{array}$ & $\begin{array}{c}0.007 \\
(0.015)\end{array}$ \\
\hline $\begin{array}{l}\text { on } 23 \text { rd through } 31 \text { st } \\
\text { of the month }\end{array}$ & $\begin{array}{c}0.024 \\
(0.018)\end{array}$ & $\begin{array}{l}-0.015 \\
(0.011)\end{array}$ & $\begin{array}{l}-0.015 \\
(0.017)\end{array}$ & $\begin{array}{l}-0.022 \\
(0.024)\end{array}$ & $\begin{array}{l}-0.007 \\
(0.020)\end{array}$ & $\begin{array}{c}0.003 \\
(0.017)\end{array}$ \\
\hline Mean Weekly Expenditures & $£ 283$ & $£ 108$ & $£ 51$ & $£ 23$ & $£ 8.1$ & $£ 36$ \\
\hline Number of Households & 7,330 & 7,317 & 7,259 & 6,524 & 6,967 & 7,299 \\
\hline \multicolumn{7}{|c|}{ Panel B. Households Where the Primary Earner is Paid Monthly } \\
\hline $\begin{array}{l}\text { Diary week begins: } \\
\text { on } 8 \text { th through } 14 \text { th } \\
\text { of the month }\end{array}$ & $\begin{array}{c}-0.033^{* *} \\
(0.015)\end{array}$ & $\begin{array}{c}0.002 \\
(0.010)\end{array}$ & $\begin{array}{l}-0.004 \\
(0.015)\end{array}$ & $\begin{array}{c}0.006 \\
(0.020)\end{array}$ & $\begin{array}{l}-0.009 \\
(0.016)\end{array}$ & $\begin{array}{l}-0.002 \\
(0.014)\end{array}$ \\
\hline $\begin{array}{l}\text { on } 15 \text { th through } 22 \text { nd } \\
\text { of the month }\end{array}$ & $\begin{array}{c}0.001 \\
(0.017)\end{array}$ & $\begin{array}{l}0.023^{* *} \\
(0.011)\end{array}$ & $\begin{array}{c}0.027 \\
(0.017)\end{array}$ & $\begin{array}{c}-0.0003 \\
(0.022)\end{array}$ & $\begin{array}{c}0.010 \\
(0.018)\end{array}$ & $\begin{array}{l}-0.007 \\
(0.016)\end{array}$ \\
\hline $\begin{array}{l}\text { on } 23 \mathrm{rd} \text { through } 31 \mathrm{st} \\
\text { of the month }\end{array}$ & $\begin{array}{c}0.111^{* * *} \\
(0.016)\end{array}$ & $\begin{array}{c}0.042^{* * *} \\
(0.011)\end{array}$ & $\begin{array}{c}0.050^{* * *} \\
(0.016)\end{array}$ & $\begin{array}{c}0.031 \\
(0.020)\end{array}$ & $\begin{array}{l}0.036^{* *} \\
(0.017)\end{array}$ & $\begin{array}{l}0.037^{* *} \\
(0.014)\end{array}$ \\
\hline Mean Weekly Expenditures & $£ 408$ & $£ 124$ & $£ 55$ & $£ 30$ & $£ 9.1$ & $£ 46$ \\
\hline Number of Households & 12,780 & 12,744 & 12,545 & 11,736 & 11,860 & 12,698 \\
\hline
\end{tabular}

${ }^{a}$ This table reports the regression coefficients from using a first difference estimator where the dependent variable is the change in the log of expenditure in the category as the dependent variable. All regressions include indicator variables for day of the month on which the diary week began and an indicator for whether the diary week is the second week of the two-week diary period. The reported standard errors are adjusted for heteroskedasticity. Panel A uses 7,347 households where the primary earner is paid weekly. Panel B uses 12,827 households where the primary earner is paid monthly. ${ }^{*},{ }^{* *}$, and ${ }^{* * *}$ represent significance at the $10 \%$, $5 \%$, and $1 \%$ levels, respectively. 


\begin{tabular}{|c|c|c|c|c|c|c|}
\hline \multicolumn{7}{|c|}{$\begin{array}{c}\text { Table 4: Impact of Paycheck Arrival on Log Weekly Expenditure } \\
\text { Households Where the Primary Earner is Paid Monthly }\end{array}$} \\
\hline \multicolumn{7}{|c|}{ Panel A. Households Without Asset Income } \\
\hline Ind. Variable & $\begin{array}{c}\text { Total } \\
\text { Spending } \\
(1) \\
\end{array}$ & $\begin{array}{c}\text { Strict } \\
\text { Non-dur. } \\
(2) \\
\end{array}$ & $\begin{array}{c}\text { Food } \\
\text { for Home } \\
(3) \\
\end{array}$ & $\begin{array}{c}\text { Food } \\
\text { Away } \\
(4) \\
\end{array}$ & $\begin{array}{c}\text { Fresh } \\
\text { Food } \\
(5) \\
\end{array}$ & $\begin{array}{c}\text { Instant } \\
\text { Cons. } \\
(6)\end{array}$ \\
\hline $\begin{array}{l}\text { Diary week: } \\
\text { overlaps paycheck } \\
\text { receipt }\end{array}$ & $\begin{array}{c}0.187^{* * *} \\
(0.032)\end{array}$ & $\begin{array}{c}0.119^{* * *} \\
(0.024)\end{array}$ & $\begin{array}{c}0.144^{* * *} \\
(0.037)\end{array}$ & $\begin{array}{c}0.071 \\
(0.044)\end{array}$ & $\begin{array}{l}0.118^{* * *} \\
(0.039)\end{array}$ & $\begin{array}{c}0.099^{* * *} \\
(0.033)\end{array}$ \\
\hline $\begin{array}{l}\text { begins week after } \\
\text { paycheck receipt }\end{array}$ & $\begin{array}{c}0.142^{* * *} \\
(0.042)\end{array}$ & $\begin{array}{c}0.082^{* * *} \\
(0.029)\end{array}$ & $\begin{array}{c}0.070 \\
(0.045)\end{array}$ & $\begin{array}{l}0.093^{*} \\
(0.056)\end{array}$ & $\begin{array}{c}0.071 \\
(0.047)\end{array}$ & $\begin{array}{l}0.098^{* *} \\
(0.041)\end{array}$ \\
\hline $\begin{array}{l}\text { begins two weeks after } \\
\text { paycheck receipt }\end{array}$ & $\begin{array}{c}0.049 \\
(0.036)\end{array}$ & $\begin{array}{l}0.044^{*} \\
(0.026)\end{array}$ & $\begin{array}{c}0.010 \\
(0.042)\end{array}$ & $\begin{array}{c}0.031 \\
(0.053)\end{array}$ & $\begin{array}{c}0.016 \\
(0.046)\end{array}$ & $\begin{array}{c}0.064^{*} \\
(0.038)\end{array}$ \\
\hline Mean Weekly Expenditures & $£ 302$ & $£ 117$ & $£ 52$ & $£ 28$ & $£ 8.2$ & $£ 43$ \\
\hline Number of Households & 2,177 & 2,174 & 2,130 & 1,971 & 1,993 & 2,162 \\
\hline \multicolumn{7}{|c|}{ Panel B. Households in Top Quartile of the Asset Income Distribution } \\
\hline Diary week: & & & & & & \\
\hline $\begin{array}{l}\text { overlaps paycheck } \\
\text { receipt }\end{array}$ & $\begin{array}{c}0.119^{* * *} \\
(0.032)\end{array}$ & $\begin{array}{c}0.016 \\
(0.020)\end{array}$ & $\begin{array}{c}0.016 \\
(0.031)\end{array}$ & $\begin{array}{c}0.055 \\
(0.041)\end{array}$ & $\begin{array}{c}0.013 \\
(0.032)\end{array}$ & $\begin{array}{c}0.054^{*} \\
(0.028)\end{array}$ \\
\hline $\begin{array}{l}\text { begins week after } \\
\text { paycheck receipt }\end{array}$ & $\begin{array}{c}0.119^{* * *} \\
(0.043)\end{array}$ & $\begin{array}{l}-0.003 \\
(0.027)\end{array}$ & $\begin{array}{c}0.027 \\
(0.038)\end{array}$ & $\begin{array}{c}0.067 \\
(0.054)\end{array}$ & $\begin{array}{c}0.016 \\
(0.040)\end{array}$ & $\begin{array}{c}0.006 \\
(0.037)\end{array}$ \\
\hline $\begin{array}{l}\text { begins two weeks after } \\
\text { paycheck receipt }\end{array}$ & $\begin{array}{c}0.018 \\
(0.038)\end{array}$ & $\begin{array}{l}-0.017 \\
(0.024)\end{array}$ & $\begin{array}{c}0.053 \\
(0.033)\end{array}$ & $\begin{array}{l}-0.013 \\
(0.049)\end{array}$ & $\begin{array}{l}-0.027 \\
(0.033)\end{array}$ & $\begin{array}{l}-0.051 \\
(0.032)\end{array}$ \\
\hline Mean Weekly Expenditures & $£ 546$ & $£ 134$ & $£ 60$ & $£ 34$ & $£ 10.2$ & $£ 51$ \\
\hline Number of Households & 3,189 & 3,176 & 3,124 & 2,925 & 2,969 & 3,165 \\
\hline
\end{tabular}

${ }^{a}$ This table reports the regression coefficients from using a first difference estimator where the dependent variable is the change in the log of expenditure in the category as the dependent variable. All regressions include indicator variables for day of the month on which the diary week began and an indicator for whether the diary week is the second week of the two-week diary period. The reported standard errors are adjusted for heteroskedasticity. Panel A uses 2,184 households that do not have any asset income. Panel B uses 10,269 households that are in the top quartile of the asset income distribution among monthly paid households. ${ }^{*},{ }^{* *}$, and $^{* * *}$ represent significance at the $10 \%, 5 \%$, and $1 \%$ levels, respectively. 


\begin{tabular}{|c|c|c|c|c|c|c|}
\hline \multicolumn{7}{|c|}{$\begin{array}{c}\text { Table 5: Impact of Paycheck Arrival on Log Weekly Expenditure }{ }^{a} \\
\text { Households Where the Primary Earner is Paid Monthly }\end{array}$} \\
\hline \multicolumn{7}{|c|}{ Panel A. Households Without Credit Cards } \\
\hline Ind. Variable & $\begin{array}{c}\text { Total } \\
\text { Spending } \\
(1) \\
\end{array}$ & $\begin{array}{c}\text { Strict } \\
\text { Non-dur. } \\
(2) \\
\end{array}$ & $\begin{array}{c}\text { Food } \\
\text { for Home } \\
(3) \\
\end{array}$ & $\begin{array}{c}\text { Food } \\
\text { Away } \\
(4) \\
\end{array}$ & $\begin{array}{c}\text { Fresh } \\
\text { Food } \\
(5) \\
\end{array}$ & $\begin{array}{c}\text { Instant } \\
\text { Cons. } \\
(6)\end{array}$ \\
\hline $\begin{array}{l}\text { Diary week: } \\
\text { overlaps paycheck } \\
\text { receipt }\end{array}$ & $\begin{array}{c}0.208^{* * *} \\
(0.030)\end{array}$ & $\begin{array}{c}0.118^{* * *} \\
(0.021)\end{array}$ & $\begin{array}{l}0.167^{* * *} \\
(0.031)\end{array}$ & $\begin{array}{l}0.101^{* *} \\
(0.042)\end{array}$ & $\begin{array}{c}0.143^{* * *} \\
(0.034)\end{array}$ & $\begin{array}{c}0.108^{* * *} \\
(0.028)\end{array}$ \\
\hline $\begin{array}{l}\text { begins week after } \\
\text { paycheck receipt }\end{array}$ & $\begin{array}{c}0.202^{* * *} \\
(0.037)\end{array}$ & $\begin{array}{c}0.095^{* * *} \\
(0.026)\end{array}$ & $\begin{array}{c}0.134^{* * *} \\
(0.038)\end{array}$ & $\begin{array}{l}0.110^{* *} \\
(0.051)\end{array}$ & $\begin{array}{c}0.053 \\
(0.041)\end{array}$ & $\begin{array}{l}0.065^{*} \\
(0.034)\end{array}$ \\
\hline $\begin{array}{l}\text { begins two weeks after } \\
\text { paycheck receipt }\end{array}$ & $\begin{array}{c}0.107^{* * *} \\
(0.035)\end{array}$ & $\begin{array}{c}0.057^{* * *} \\
(0.022)\end{array}$ & $\begin{array}{c}0.097^{* * *} \\
(0.035)\end{array}$ & $\begin{array}{l}0.110^{* *} \\
(0.050)\end{array}$ & $\begin{array}{c}0.061 \\
(0.040)\end{array}$ & $\begin{array}{l}0.066^{* *} \\
(0.034)\end{array}$ \\
\hline Mean Weekly Expenditures & $£ 277$ & $£ 104$ & $£ 49$ & $£ 22$ & $£ 8.0$ & $£ 35$ \\
\hline Number of Households & 2,550 & 2,549 & 2,519 & 2,280 & 2,386 & 2,536 \\
\hline \multicolumn{7}{|c|}{ Panel B. Households With Credit Cards } \\
\hline Diary week: & & & & & & \\
\hline $\begin{array}{l}\text { overlaps paycheck } \\
\text { receipt }\end{array}$ & $\begin{array}{c}0.130^{* * *} \\
(0.017)\end{array}$ & $\begin{array}{c}0.056^{* * *} \\
(0.011)\end{array}$ & $\begin{array}{c}0.068^{* * *} \\
(0.018)\end{array}$ & $\begin{array}{l}0.047^{* *} \\
(0.022)\end{array}$ & $\begin{array}{l}0.035^{*} \\
(0.018)\end{array}$ & $\begin{array}{c}0.049^{* * *} \\
(0.015)\end{array}$ \\
\hline $\begin{array}{l}\text { begins week after } \\
\text { paycheck receipt }\end{array}$ & $\begin{array}{c}0.106^{* * *} \\
(0.022)\end{array}$ & $\begin{array}{l}0.027^{*} \\
(0.014)\end{array}$ & $\begin{array}{l}0.049^{* *} \\
(0.022)\end{array}$ & $\begin{array}{c}0.071^{* * *} \\
(0.028)\end{array}$ & $\begin{array}{c}0.020 \\
(0.023)\end{array}$ & $\begin{array}{l}0.047^{* *} \\
(0.020)\end{array}$ \\
\hline $\begin{array}{l}\text { begins two weeks after } \\
\text { paycheck receipt }\end{array}$ & $\begin{array}{c}0.022 \\
(0.019)\end{array}$ & $\begin{array}{c}0.00002 \\
(0.013)\end{array}$ & $\begin{array}{c}0.031 \\
(0.020)\end{array}$ & $\begin{array}{c}0.023 \\
(0.026)\end{array}$ & $\begin{array}{l}-0.001 \\
(0.021)\end{array}$ & $\begin{array}{c}0.008 \\
(0.019)\end{array}$ \\
\hline Mean Weekly Expenditures & $£ 440$ & $£ 129$ & $£ 57$ & $£ 32$ & $£ 9.3$ & $£ 49$ \\
\hline Number of Households & 10,230 & 10,195 & 10,026 & 9,456 & 9,474 & 10,162 \\
\hline
\end{tabular}

${ }^{a}$ This table reports the regression coefficients from using a first difference estimator where the dependent variable is the change in the log of expenditure in the category as the dependent variable. All regressions include indicator variables for day of the month on which the diary week began and an indicator for whether the diary week is the second week of the two-week diary period. The reported standard errors are adjusted for heteroskedasticity. Panel A uses 2,556 households that do not have a credit card. Panel B uses 10,269 households that report having at least one credit card. ${ }^{*},{ }^{* *}$, and ${ }^{* * *}$ represent significance at the $10 \%, 5 \%$, and $1 \%$ levels, respectively. 


\begin{tabular}{|c|c|c|c|c|c|c|}
\hline \multicolumn{7}{|c|}{$\begin{array}{c}\text { Appendix Table 1: Impact of Paycheck Arrival on the Amount of Exp } \\
\text { Non-Zero Expenditure Diary Weeks } \\
\text { Households Where the Primary Earner is Paid Monthly }\end{array}$} \\
\hline Ind. Variable & $\begin{array}{c}\text { Total } \\
\text { Spending } \\
(1)\end{array}$ & $\begin{array}{l}\text { Strict } \\
\text { Non-dur. } \\
(2)\end{array}$ & $\begin{array}{l}\text { Food } \\
\text { for Home } \\
(3) \\
\end{array}$ & $\begin{array}{l}\text { Food } \\
\text { Away } \\
(4)\end{array}$ & $\begin{array}{c}\text { Fresh } \\
\text { Food } \\
(5)\end{array}$ & $\begin{array}{l}\text { Instant } \\
\text { Cons. } \\
(6)\end{array}$ \\
\hline $\begin{array}{l}\text { Diary week: } \\
\text { overlaps paycheck } \\
\text { receipt }\end{array}$ & $\begin{array}{l}62.0^{* * *} \\
(18.8)\end{array}$ & $\begin{array}{l}8.93^{* * *} \\
(1.26)\end{array}$ & $\begin{array}{c}5.79^{* * *} \\
(0.74)\end{array}$ & $\begin{array}{l}1.41^{*} \\
(0.73)\end{array}$ & $\begin{array}{l}0.40^{* *} \\
(0.15)\end{array}$ & $\begin{array}{c}2.09^{* * *} \\
(0.79)\end{array}$ \\
\hline $\begin{array}{l}\text { begins week after } \\
\text { paycheck receipt }\end{array}$ & $\begin{array}{c}87.8^{* * *} \\
(31.1)\end{array}$ & $\begin{array}{c}6.14^{* * *} \\
(1.62)\end{array}$ & $\begin{array}{c}3.94^{* * *} \\
(0.99)\end{array}$ & $\begin{array}{c}1.52 \\
(0.98)\end{array}$ & $\begin{array}{c}0.24 \\
(0.18)\end{array}$ & $\begin{array}{l}1.40 \\
(1.04)\end{array}$ \\
\hline $\begin{array}{l}\text { begins two weeks after } \\
\text { paycheck receipt }\end{array}$ & $\begin{array}{c}21.0 \\
(16.6)\end{array}$ & $\begin{array}{l}1.61 \\
(1.54)\end{array}$ & $\begin{array}{l}2.50^{* *} \\
(1.07)\end{array}$ & $\begin{array}{c}0.10 \\
(0.75)\end{array}$ & $\begin{array}{l}0.002 \\
(0.17)\end{array}$ & $\begin{array}{l}-0.19 \\
(0.80)\end{array}$ \\
\hline Mean Weekly Expenditures & $£ 408$ & $£ 125$ & $£ 56$ & $£ 32$ & $£ 9.5$ & $£ 46$ \\
\hline Number of Households & 12,780 & 12,744 & 12,545 & 11,736 & 11,860 & 12,698 \\
\hline
\end{tabular}

${ }^{a}$ This table reports the regression coefficients from using a first difference estimator where the dependent variable is the change in (the level of) weekly expenditure in the category as the dependent variable. All regressions include indicator variables for day of the month on which the diary week began and an indicator for whether the diary week is the second week of the two-week diary period. The reported standard errors are adjusted for heteroskedasticity. The sample is comprised of 12,827 households where the primary earner is paid monthly. ${ }^{*}$, ${ }^{* *}$, and ${ }^{* * *}$ represent significance at the $10 \%, 5 \%$, and $1 \%$ levels, respectively. 


\begin{tabular}{|c|c|c|c|c|}
\hline \multicolumn{5}{|c|}{$\begin{array}{l}\text { Appendix Table 2: Summary Statistics } \\
\text { A } \\
\text { Households Where the Primary Earner is Paid Weekly }\end{array}$} \\
\hline & \multicolumn{4}{|c|}{ First Day of Diary Week Is } \\
\hline & $\begin{array}{l}\text { 1st to } 7 \text { th } \\
\text { of Month }\end{array}$ & $\begin{array}{l}8 \text { th to } 14 \text { th } \\
\text { of Month }\end{array}$ & $\begin{array}{l}15 \text { th to } 21 \mathrm{st} \\
\text { of Month }\end{array}$ & $\begin{array}{l}22 \text { nd to } 31 \text { st } \\
\text { of Month }\end{array}$ \\
\hline Primary Earner's: & & & & \\
\hline Age & $\begin{array}{l}40.3 \\
(0.24)\end{array}$ & $\begin{array}{l}40.2 \\
(0.21)\end{array}$ & $\begin{array}{c}40.0 \\
(0.22)\end{array}$ & $\begin{array}{c}40.0 \\
(0.24)\end{array}$ \\
\hline Gender $($ Male $=1)$ & $\begin{array}{l}0.86 \\
(0.01)\end{array}$ & $\begin{array}{c}0.87 \\
(0.01)\end{array}$ & $\begin{array}{c}0.86 \\
(0.01)\end{array}$ & $\begin{array}{c}0.85 \\
(0.01)\end{array}$ \\
\hline Years of Education & $\begin{array}{c}9.7 \\
(0.03)\end{array}$ & $\begin{array}{c}9.6 \\
(0.03)\end{array}$ & $\begin{array}{c}9.7 \\
(0.03)\end{array}$ & $\begin{array}{c}9.7 \\
(0.03)\end{array}$ \\
\hline Weekly Income & $\begin{array}{l}312 \\
(4)\end{array}$ & $\begin{array}{c}305 \\
(3)\end{array}$ & $\begin{array}{l}312 \\
(4)\end{array}$ & $\begin{array}{l}323 \\
(5)\end{array}$ \\
\hline Weekly Household Income & $\begin{array}{l}426 \\
(5)\end{array}$ & $\begin{array}{l}416 \\
(4)\end{array}$ & $\begin{array}{l}430 \\
(5)\end{array}$ & $\begin{array}{l}440 \\
(6)\end{array}$ \\
\hline Number of Households & 1,681 & 2,138 & 1,808 & 1,720 \\
\hline
\end{tabular}

${ }^{a}$ Standard errors are reported in parentheses. 


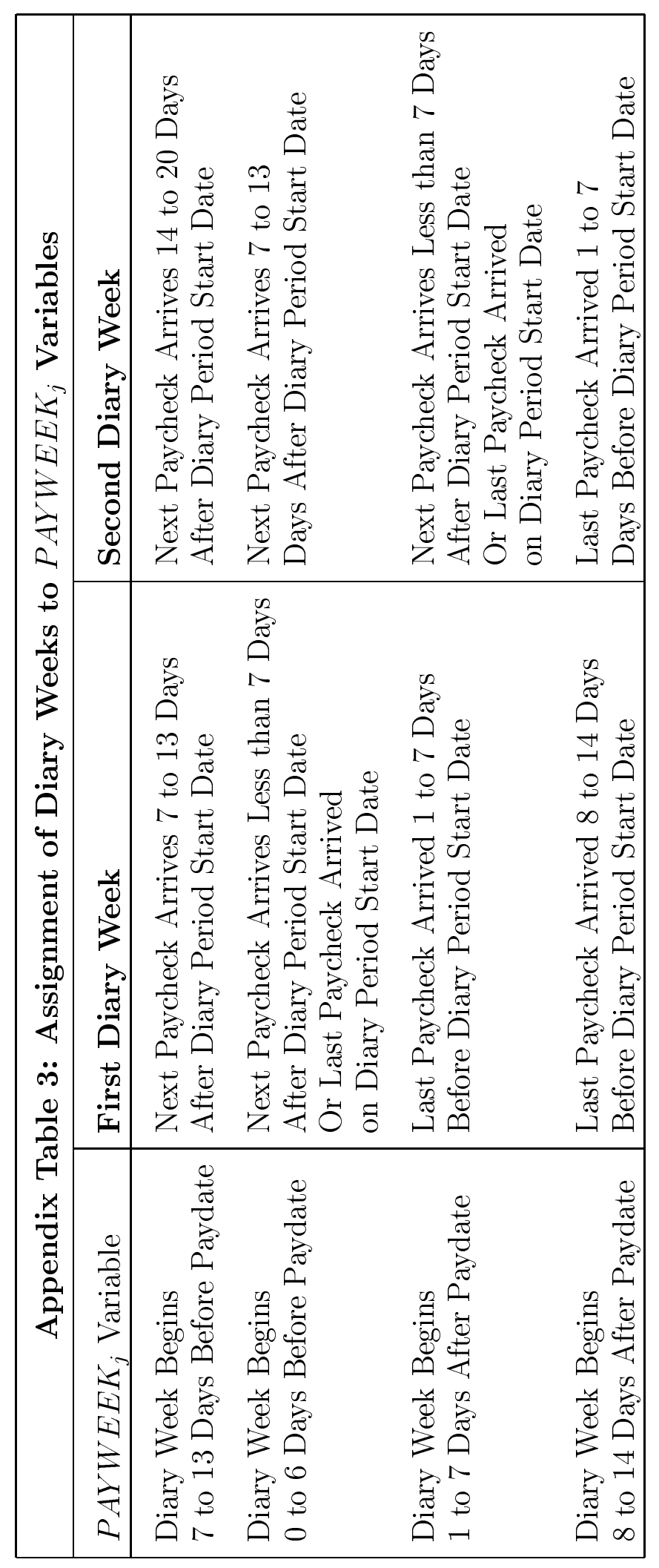

